\title{
The relevance of management accounting education at South African tertiary institutions
}

\section{Shotter, FJ de Hart, GJ Plant}

School of Accountancy, University of Pretoria

\section{EM Louw}

Department of Statistics, University of Pretoria

\section{AJ Pienaar}

Accounting Training Corporation of South Africa (ATCOR)

Received: January 1999

SAJAR

Revised: December 1999, August 2000

Vol 14 no. 2

Accepted: September 2000

This study examines the extent of the gap between education and practice, in respect of management accounting in South Africa. The investigation is carried out by means of two surveys; the first among universities and technikons to determine what is taught by tertiary institutions and the second among consultants to ascertain what is being practised.

It finds a significant overemphasis by education of simplistic mathematical models and quantitative techniques at the expense of strategic management accounting and performance measurement techniques.

A literature study indicates that the relevance of the subject might be enhanced through closer co-operation between education and practice as well as multidisciplinary research. A broader view, incorporating organisational and behavioural perspectives on management accounting, should be taken. 


\section{KEY WORDS}

Management accounting education

Management accounting education gap

\section{Contact}

M Shotter, School of Accountancy, University of Pretoria, Lynnwood Road, Pretoria Email: shotter@iafrica.com

\section{INTRODUCTION}

\section{Background}

Management accounting has been the topic of much criticism during the second half of the previous century, and the relevance thereof in the modern day and age, has often been questioned (Simon, 1959; Lovell, 1988; Shank, 1989). Although some critics such as Goldratt and $\operatorname{Cox}(1984)$ have viewed cost accounting as the major obstacle to making US manufacturing competitive, others have proposed alterations to, if not an expansion of, the role of accounting.

The relevance debate concerning management accounting can however not be complete, without reference being made to the seminal text of Johnson and Kaplan (1987), namely "Relevance Lost: The Rise and Fall of Management Accounting". Their criticisms against management accounting can be summarised in four lines of thought. Firstly, they observe limited evidence of technical development within management accounting practice, in response to the major changes in manufacturing technology in the (then) previous 15 years. Secondly, Johnson and Kaplan (1987) held that management accounting was the captive of financial reporting. Thirdly, they levelled their criticism at academics involved in management accounting. According to them, their research and the textbook tradition had focused on sophisticated approaches for simplistic economic-based models, bearing little relation to the complexities in practice. This resulted, according to them, in a gap between education and practice. The final criticism of Johnson and Kaplan (1987) addresses the history of management accounting. Instead of viewing management accounting as a recent development, as is suggested by some writers, they argue that it is necessary to recognise its origins in the first half of the nineteenth century.

\section{The purpose and scope of the research}

This article examines Johnson and Kaplan's third line of criticism, namely the relevance of management accounting education, for as far as it applies in a South African context. 
More specifically, it investigates the extent of the gap between management accounting education and practice by means of an empirical study.

The scope of the empirical study is limited to South African universities and technikons, representing education, and South African management consultants, representing practice. These surveys were carried out during 1997 and 1998 respectively. The paper also explores possible solutions to narrow the gap, by means of a literature study.

There are several perspectives on the subject of management accounting including pluralism (Hopper and Powell, 1985), interpretive approaches (Puxty, 1993) as well as the radical theories. Examples of these are the dialectical approach to social analysis by Neimark and Tinker (1986), the labour process approach (Hopper and Armstrong, 1991), the Foucaldian perspective (Loft, 1991, Miller and O'Leary, 1987, Arrington and Francis, 1989) and structuration theory (Macintosh and Scapens, 1990). Due to the fact that most conventional textbooks are however based on neo-classical economics (Kelly and Pratt, 1992, Scapens, 1991, Neimark and Tinker, 1986, Drury, 1996, Hansen and Mowen, 1994, Rayburn, 1996), it was decided to limit this investigation to the neoclassical economic approach to management accounting. Similarly, the general textbook definition of management accounting, namely that section of accounting concerned with the provision of information to people within the organisation (Drury, 1996:4; Hansen and Mowen, 1994: 5; Rayburn, 1996: 5), is subscribed to for the purpose of this article.

\section{EMPIRICAL RESEARCH METHODOLOGY}

\section{Research design and sample plan}

The empirical work was carried out in two stages. The first stage consisted of a survey amongst tertiary institutions that lecture management accounting in South Africa, to determine the contents of their syllabi. The second stage comprised a survey amongst management consultants that specialise in the area of management accounting, in order to establish the management accounting practices in South Africa.

Both surveys were carried out by means of questionnaires. In order to facilitate a comparison between the results of the two surveys, the contents of the questionnaires are essentially the same - only the introductory wording differs. The first questionnaire seeks to establish the level of knowledge required from students, whilst the second investigates the level of knowledge required from practitioners. The questionnaires were tested among academics and practitioners to ensure that they would be understandable to both parties and to avoid the possibility of a bias due to the post qualifying experience of the practitioners. The questions were based on a five point Likert scale. The institutions and consultants were requested to indicate the level of knowledge required from students and practitioners respectively. The levels were: 


\begin{tabular}{|ll|}
\hline 0$) \quad$ unsure of level of presentation (education) \\
unsure of level of knowledge required (practice) \\
not presented (education) \\
no knowledge required (practice)
\end{tabular}

The first questionnaire was circulated amongst 41 departments at tertiary institutions, comprising of 25 departments at universities and 16 at technikons, being all the technikons and universities that were listed by the South African Department of Education in 1997. Twenty departments from tertiary institutions responded, namely 11 from universities and 9 from technikons. The overall response is $48,78 \%$, while the individual response rates for the universities and technikons are $44 \%$ and $56,25 \%$, respectively. The results can thus be accepted as representative of both forms of institutions. The responding institutions represent 9937 students of whom 6591 are from universities and 3346 from technikons. The number of students was taken as being the total number of students from first year to fourth year including honours, but excluding masters. The survey was restricted to universities and technikons due to practical considerations. Where institutions lectured management accounting in more than one department or in different locations, the departments were requested to complete separate questionnaires, since it was assumed that the contents of the syllabi might differ between departments.

The number of students per institution varies from as little as 15 to up to 2500 . To gain an impression of the level of knowledge required from students nationally, the responses of the lecturers were weighted according to the number of students per institution and the responses of the lecturers were thus deemed to be representative of the knowledge required of their students.

In order to determine management accounting practice in South Africa, two possible routes were identified namely either approaching companies or approaching management consultants who have insight into the management accounting practices of a wide range of companies. The reason why it was decided to establish the management accounting practices from the perspective of management consultants rather than to approach companies, is twofold. A trend currently exists whereby researchers concentrate on approaching individual companies directly; in particular the companies listed on the Johannesburg Stock Exchange (JSE). Research results are thus often restricted to companies listed on the JSE. These companies have also become reluctant to respond due to the overwhelming number of empirical research requests, resulting in a low response rate. Practically, it is also easier and more cost-effective to 
approach the management consultants and the possibility of direct contact to ensure a higher response rate, is greater.

The management consultants that were included in the survey comprise 11 firms. The consultants were identified as leading consultants by referring to the rating of the Professional Management Review to identify the top ten consulting firms in South Africa. The rating was based on a survey amongst 100 of South Africa's 2000 largest corporations who had made use of the services of management consultants during the then past 12 months (Krige, 1998: 61). One other firm of consultants was included since it specialises in management and cost accounting. Eight firms responded, resulting in a $72,7 \%$ response rate. The results were weighted according to the number of consultants in the organisation that specialise in the field of management accounting, in order to calculate a weighted average level of knowledge. The views of the consultants were thus deemed to be representative of the views of all the consultants of that firm, that specialise in management accounting. In one instance, where the respondent failed to indicate the number of consultants, the average number of consultants of the survey was applied.

\section{Technique for statistical analysis}

The median is applied as an average scale measurement since it is deemed to be more representative than the arithmetic mean. Due to the fact that neither of the responses of the education or practice groups (populations) is normally distributed, it was decided to perform the U-test of Mann-Whitney, also known as the rank sum test of Wilcoxon, which is distribution free. The U-test of Mann-Whitney is designed to test the null hypothesis of no difference between the medians of the two populations, in respect of each focus area of management accounting at a $5 \%$ level of significance. The alternative hypothesis indicates a difference between the two medians of the populations. Where the p-value is less than the level of significance $(0.05)$, the null hypothesis is rejected in favour of the alternative, indicating that there is a significant difference between the medians of the populations. Where the p-value is less than 0.01 it is described as highly significant. The dispersion around the median is measured by means of a quartile deviation, which is defined as the average distance between the first and third quartiles.

\section{SURVEYS OF MANAGEMENT ACCOUNTING EDUCATION AND PRACTICE IN SOUTH AFRICA}

\section{Introduction}

In the following section the views of lecturers representing education and of consultants representing practice are compared. 
In order to make the investigation more manageable, the subject is divided into the following areas of focus: information for planning and control, decision-making, product costing and divisional performance measurement as well as strategic management accounting. Quantitative techniques are grouped together in a separate section.

\section{Planning and control}

The median scale values in respect of the results received from the tertiary institutions and the consultants, regarding the planning and control topics are summarised below.

\begin{tabular}{|l|l|l|}
\hline & Education & Practice \\
\hline Budgeting & 3.5 & 4 \\
\hline Zero-based budgeting & 3 & 2 \\
\hline Activity based budgeting & 3 & 4 \\
\hline Strategic planning & 4 & 3 \\
\hline Behavioural aspects of accounting control systems & 2 & 4 \\
\hline Standard costing & 3.2 & 2 \\
\hline Organisational and social aspects of management accounting & 2 & 2 \\
\hline
\end{tabular}

The overall medians of the whole section of planning and control, are 2.814 in respect of education and 2.857 in respect of practice. The p-value of 0.4583 indicates that there is no significant difference between the medians of the two populations.

Regarding the individual planning and control topics, the maximum quartile deviation of the individual is 1 , which serves as an indication of the dispersion of the observations around the medians. Standard costing appears to be overemphasised by education whilst the behavioural aspects of accounting control do not appear to receive sufficient attention.

The finding regarding standard costing is in contradiction with Japanese, American, British and Irish firms where the application of standard costing in practice appears to be prevalent. According to Bromwich and Bhimani (1994: 173) some sixty percent of the Japanese firms use standard costing, while Cohen and Paquette (in Bromwich and Bhimani, 1994: 200) found in a study of manufacturing companies in the United States of America, that $67 \%$ of the companies applied standard costing systems. Based on a study of 423 British companies Lyall, Okoh and Puxty's (in Bromwich and Bhimani, 1994) concur by stating that the "demise of standard costing and budgetary control 
systems appears to be a little premature". This was also the case in Ireland where Clarke (1993: 9) found that $85 \%$ of the respondents used a standard costing system. Similar to South African practice, budgetary controls also feature strongly in Japan according to Bromwich and Bhimani (1994: 173), and in Ireland all of the 320 manufacturing organisations surveyed indicated that they made use of budgeting control (Clarke, 1993:7).

\section{Decision-making}

The median scale values in respect of the results received from the tertiary institutions and the consultants, regarding decision-making are summarised below.

\begin{tabular}{|c|l|l|}
\hline & Education & Practice \\
\hline Cost-volume-profit analysis & 3.25 & 2 \\
\hline Relevant costs for decision-making & 4 & 3 \\
\hline Pricing: Economist's model & 2 & 2 \\
\hline Pricing policies e.g. price penetration and price skimming & 2 & 2 \\
\hline The effect of risk and uncertainty on decision making & 3 & 2 \\
\hline $\begin{array}{c}\text { Standard deviation and coefficient of variation } \\
\text { Value of perfect information }\end{array}$ & 2 & 2 \\
\hline Decision trees & 3 & 2 \\
\hline $\begin{array}{c}\text { Met present value } \\
\text { Adjusted present value }\end{array}$ & 4 & 3 \\
\hline Eapital budgeting techniques & 3 & 3 \\
\hline Project specific financing and capital budgeting & 2 & 3 \\
\hline Effect of risk on capital budgeting & 3 & 2 \\
\hline Effect of inflation on capital budgeting & 2 & 2 \\
\hline
\end{tabular}

The overall medians of the whole section of decision-making, are 2.375 in respect of education and 2.333 in respect of practice. The p-value of 0.0052 indicates that there is a highly significant difference between the medians of the two populations. 
In respect of the individual observations, the quartile deviations in respect of the adjusted present value and the modified internal rate of return methods are both 1.5. The maximum quartile deviation regarding the other observations are 1 . It seems as if the tertiary institutions in South Africa place more emphasis on the importance of costvolume-profit analysis, relevant costs as well as techniques for addressing risk and uncertainty in decision-making, than practice.

\section{Product costing}

The median scale values in respect of the results received from the tertiary institutions and the consultants, regarding product costing are summarised below.

\begin{tabular}{|l|l|l|}
\hline & Education & Practice \\
\hline Valuation of inventory & 3 & 3 \\
\hline Production management strategies: & & \\
\hline \multicolumn{1}{|c|}{ Material requirements planning (MRP) } & 2 & 4 \\
\hline $\begin{array}{l}\text { Treatment of direct and indirect labour costs for product } \\
\text { costing }\end{array}$ & 3 & 4 \\
\hline Incentive schemes and the correct treatment of related costs & 3 & 3 \\
\hline Treatment of overheads for product costing & 3.5 & 4 \\
\hline Allocation of overheads on an activity based costing basis & 3 & 4 \\
\hline Job costing & 3 & 2 \\
\hline Process costing & 3 & 2 \\
\hline Treatment of joint and by-products & 3 & 2 \\
\hline Costing of products on the variable and absorption bases & 4 & 2 \\
\hline
\end{tabular}

The overall medians of the whole section of product costing, are 2.982 in respect of education and 3 in respect of practice. The p-value of 0.8358 indicates that there is no significant difference between the medians of the two populations.

Regarding the individual observations, the highest quartile deviation is 1.5 in respect of incentive schemes, while the quartile deviations of the rest of the observations do not exceed I. It appears as if too little emphasis is placed by education on MRP I and on MRPII in particular, whilst conventional topics such as job costing, process costing, the 
treatment of joint and by-products as well as variable and absorption costing are overemphasised.

The finding that costing techniques such as process costing appears to be of declining importance in practice in South Africa corresponds with that of a study amongst Japanese firms. Less than 30 percent of the firms use job costing whilst only about 50 percent use process costing, and about 30 percent of the firms use both systems (Bromwich and Bhimani, 1994: 173).

\section{Divisional performance measurement}

The median scale values in respect of divisional performance measurement are summarised below.

\begin{tabular}{|l|l|l|}
\hline & Education & Practice \\
\hline Return on investment & 4 & 4 \\
\hline Residual income & 4 & 3 \\
\hline Economic value added (trademark) & 2 & 3 \\
\hline Transfer pricing: calculation of an optimal price & 3.4 & 3 \\
\hline Optimal transfer price for taxation purposes & 1 & 2 \\
\hline
\end{tabular}

The overall medians of the whole section of divisional performance measurement, are 3 in respect of education and 3.2 in respect of practice. The p-value of 0.0001 indicates that there is a highly significant difference between the medians of the two populations, with more emphasis on divisional performance measurement by practice than placed by education. The importance of the dispersion around the medians is evident in this comparison. Although the overall medians appear to be similar, the narrow dispersion of the two groups causes the difference to be significant.

With regard to the individual topics, the maximum quartile deviation is 1.5 in respect of the response of education regarding residual income and 1 in respect of the other observations. There appears to be an inconsistency regarding the application of residual income and EVA. These two techniques are essentially the same and fundamentally the same formulae are applied in both instances. However, whereas education deem the residual income technique to be more important than practice, the opposite is true of EVA. It is possible that the residual income technique is more well known in education, whilst EVA is more popular in practice. It would appear that a need exists of knowledge in practice in respect of an optimal transfer price for taxation purposes, which is not currently addressed by education. 


\section{Strategic management accounting}

Strategic management accounting developed largely in response to the criticism levelled against management accounting in the 1980's due to its lack of a strategic perspective. It derives its name from its endeavour to generate accounting information which supports attempts by senior management to achieve and sustain a strategic position in the market place (Shank and Govindarajan, 1989: xi; Roslender, 1996: 536).

Initially a variety of new techniques were promoted, including activity based costing (Cooper and Kaplan, 1988), backflush accounting (Bhimani and Bromwich, 1991) as well as throughput accounting (Galloway and Waldron in Du Plooy, 1998). This was subsequently followed by life cycle costing (Berliner and Brimson, 1988); strategic cost analysis and value chains (Shank and Govindarajan, 1989) and target costing (Hiromoto, 1988).

Further developments include generic approaches such as activity-based management (Cooper and Kaplan, 1991), balanced scorecard (Kaplan and Norton, 1992) and strategic cost management as well as continuous performance improvement (Turney and Anderson, 1989). Total quality management can be added to these approaches.

The median scale values in respect of strategic management accounting are as follows:

\begin{tabular}{|l|l|l|}
\hline & Education & Practice \\
\hline Customer profitability analysis on an ABC basis & 3 & 4 \\
\hline Activity based management & 3 & 4 \\
\hline Value analysis/ value engineering & 1 & 4 \\
\hline Cost reduction schemes & 2 & 4 \\
\hline Target costing & 3 & 3 \\
\hline Life cycle costing & 2 & 3 \\
\hline Cost benefit analysis & 3 & 3 \\
\hline Benchmarking & 2 & 4 \\
\hline Production management strategies: & & \\
\hline \multicolumn{1}{|c|}{ Just-in-time (JT) } & 3 & 3 \\
\hline Optimal production technology (OPT) & 1 & 3 \\
\hline Backflush accounting & 1 & 2 \\
\hline Throughput accounting & 2 & 2 \\
\hline
\end{tabular}


The overall medians of the whole section of strategic management accounting, are 2.083 in respect of education and 3.167 in respect of practice. The p-value of 0.0001 indicates that a highly significant difference exists between the medians of the two populations, with a much higher emphasis being placed by practice on strategic management accounting.

In respect of the individual observations, the maximum quartile deviation is 1 . Value analysis, cost reduction schemes, benchmarking and optimal production technology production strategies require the urgent attention of the lecturers at tertiary institutions in order to narrow the gap between education and practice.

Similarly, Bromwich and Bhimani (1994: 232) observed a greater emphasis on strategic matters such as quality, delivery performance and customer satisfaction in the United Kingdom in practice. They also recommended that management accountants should cultivate an understanding of marketing problems and processes and play a more integral role in the strategic activities of the organisation.

\section{Quantitative techniques}

Finally, the median scale values in respect of quantitative techniques are summarised.

\begin{tabular}{|l|l|l|}
\hline & Education & Practice \\
\hline Inventory: economic order quantities & 3 & 2 \\
\hline Inventory: optimal safety stock levels & 3 & 2 \\
\hline Linear programming & 3 & 2 \\
\hline Linear programming: shadow prices & 3 & 2 \\
\hline Linear programming: simplex method & 3 & 2 \\
\hline Regression analysis & 2 & 2 \\
\hline Learning curve theory & 4 & 2 \\
\hline Sensitivity analysis & 3 & 3 \\
\hline
\end{tabular}

The overall medians of the whole section of quantitative techniques, are 2.875 in respect of education and 2 in respect of practice. The p-value of 0.0001 indicates that there is a highly significant difference between the medians of the two populations, with a clear overemphasis by education. 
Regarding the individual observations, the maximum quartile deviation, which serves as an indication of the dispersion of the observations around the median, is I. The levels of knowledge required in respect of inventory models, linear programming and learning curve theory in particular, appear to be much higher in education than in practice. It is unlikely that practitioners are unaware of these techniques since these topics have been part of the curriculum of tertiary institutions and professional institutes for a number of decades. A more probable explanation is that they have found simpler techniques to be more optimal when the costs and benefits are considered (Drury 1990, Scapens, 1984).

In a survey in the United Kingdom of the employers' views on the role of quantitative skills in management accounting practice, Spencer and Francis (1998: 64-65) found that $68 \%$ of employers are of the opinion that strong mathematical skills are essential. However their survey revealed a low level of actual use of advanced quantitative techniques. Drury (1996: 855) also observed an insignificant use of quantitative techniques such as linear programming, statistical variance investigation models and regression techniques for estimating cost functions, in practice.

\section{Summary of the findings}

In order to provide an overview of the results of the study, the medians of the focus areas as well as the results of the U-test of Mann-Whitney are summarised in the following table.

\begin{tabular}{|l|l|l|l|l|l|}
\hline \multicolumn{1}{|c|}{$\begin{array}{c}\text { Management } \\
\text { accounting } \\
\text { Focus area (sections) }\end{array}$} & $\begin{array}{c}\text { Education } \\
\text { Median }\end{array}$ & $\begin{array}{c}\text { Practice } \\
\text { Median }\end{array}$ & $\begin{array}{c}\text { Test } \\
\text { statistic } \\
\text { Normal } \\
\text { approx. } \\
(\mathbf{z})\end{array}$ & $\begin{array}{c}\text { Exceedance } \\
\text { probability } \\
\text { (p value) }\end{array}$ & \multicolumn{1}{|c|}{ Conclusion } \\
\hline $\begin{array}{l}\text { Planning, forecasting } \\
\text { and control }\end{array}$ & 2.814 & 2.857 & 0.7417 & 0.4583 & $\begin{array}{l}\text { No significant } \\
\text { difference }\end{array}$ \\
\hline Decision-making & 2.375 & 2.333 & -2.794 & 0.0052 & $\begin{array}{l}\text { Highly significant } \\
\text { difference }\end{array}$ \\
\hline Product costing & 2.982 & 3 & 0.2073 & 0.8358 & $\begin{array}{l}\text { No significant } \\
\text { difference }\end{array}$ \\
\hline $\begin{array}{l}\text { Divisional } \\
\text { performance } \\
\text { measurement }\end{array}$ & 3 & 3.2 & 4.4257 & 0.0001 & $\begin{array}{l}\text { Highly significant } \\
\text { difference }\end{array}$ \\
\hline $\begin{array}{l}\text { Strategic management } \\
\text { accounting }\end{array}$ & 2.083 & 3.167 & 7.56718 & 0.0001 & $\begin{array}{l}\text { Highly significant } \\
\text { difference }\end{array}$ \\
\hline $\begin{array}{l}\text { Quantitative } \\
\text { techniques }\end{array}$ & 2.875 & 2 & -10.0286 & 0.0001 & $\begin{array}{l}\text { Highly significant } \\
\text { difference }\end{array}$ \\
\hline
\end{tabular}

The quartile deviations of the focus areas are all less than or equal to 0.94 . According to the results there are no significant differences between the levels of knowledge required 
by education and practice, in respect of the sections of planning and control and product costing. However, highly significant differences exist in the areas of decision-making, performance measurement, strategic management accounting and quantitative techniques.

There does therefore appear to be a significant gap between education and practice with regard to management accounting. It can mostly be ascribed to an overemphasis of quantitative and decision-making techniques at the expense of newer developments. This exaggeration of the importance of quantitative techniques might be partly explained by the criticism levelled against academics in 1959 by the Ford Foundation and the Carnegie Corporation. Their reports inter alia called for a more solid theoretical foundation and the use of more scientific approaches to research. In response, articles written by academics applying mathematical modelling to accounting problems has dominated the academic literature while practitioner authorship has virtually disappeared (Maher, 1995: 72).

On the other hand, there appears to be a general lack of emphasis by education on the newer topics that can be categorised as strategic management accounting. This might be ascribed to the inability of education to keep up with the changing business environment. During the past three decades organisations have had to face dramatic changes in the competitive, manufacturing and information world (Drury, 1996: 21, Berliner and Brimson, 1988, Carnoy, Castells, Cohen and Cardoso, 1993:5). All these changes have an affect on the format and content of information required by management and therefore on the task of the management accountant.

\section{RECOMMENDATIONS FOR ADDRESSING THE GAP}

Although it would be unwise to suggest a simple solution for addressing such a complex problem, the contribution that a closer relationship between education and practice as well as a wider perspective on research might make, warrant further examination.

Lovell (1988) recommends closer co-operation between management accounting practitioners and academics in order to narrow the gap between education and practice. His view is shared by Siegel and Sorenson (1994: 30) as well as Williamson (1989:3435) who suggests that a partnership should be formed between the authors of management accounting textbooks, the researchers, the educators and the practitioners. Hendricks (1993: 50) proposes internships by management accounting educators in practice, whilst Shillinglaw (1980: 16) suggests that we need to devote more effort to the task of identifying the problems of practice for the purpose of research. However, an overemphasis of positive research has the potential danger of causing the content of the subject to stagnate, simply reinforcing theory by practice, and excluding any new theoretical ideas. Vorster (1995) reminds us that accounting theory is a prerequisite for 
good accounting practice, and it is an unsatisfactory state of affairs when accounting practices are applied at random without a rigorous theoretical underpinning. According to Kaplan (1994: 258) "the new management accounting will come from scholars who are actively involved in practice, alternating among careful observation and documentation, theory development, and intervention and participation in organisational change processes".

Scapens (1991: 221) suggests that progress towards understanding the role of management accounting in practice, is likely to come from a suitable blend of economic, organisational and behavioural approaches to research. To exploit these approaches to the full there is a need for collaborative research, in which researchers trained in economics, organisational theory, behavioural science and accounting, study the practice of management accounting. This is also the recommendation of Bhimani (1994) who suggests that in order to break from the existing preoccupation with technical issues that are divorced from the organisational context, research perspectives should be sought from outside the field. Shillinglaw (1980: 16) agrees and suggests that we need to expand our horizons to include subject matter we have never thought of as managerial accounting and develop multi-disciplinary research teams to deal with problems that transcend the boundaries of the managerial accountant's zone of unique experience (ibid. 16).

\section{CONCLUSION}

The study confirms that there is a gap between what is taught at tertiary institutions and what is practiced in respect of the subject of management accounting. Strategic management accounting and performance measurement require more attention by education whilst quantitative and decision-making techniques are overemphasised. These findings support Johnson and Kaplan's (1987) criticism that education seems to focus on sophisticated approaches for simplistic economic-based models that are often irrelevant in practice.

The gap could be narrowed through closer co-operation between education and practice as well as a suitable blend of economic, organisational and behavioural approaches to research. To exploit these approaches to the full, a need exists for collaborative research where researchers who specialise in accounting, economics, organisational theory as well as behavioural sciences, study the theory and practice of management accounting.

\section{REFERENCES}

Arrington, C.E. and J. R. Francis. (1989). Letting the chat out of the bag: Deconstruction, Privilege and Accounting Research, Accounting, Organizations and Society, 14(1/2): 1-28. 
Berliner, C. and Brimson, J.A. (eds.). (1988). Cost Management in Today's Advanced Manufacturing: the CAM-I Conceptual design, Harvard Business School Press: Boston.

Bhimani, A. and Bromwich, M. (1991). Accounting for Just-in-Time manufacturing systems, CMA: The Management Accounting Magazine, 65 (1): 31-34.

Bhimani, A. (1994). Modern cost management: putting the organization before the technique, International Journal of Production Economics, 36(1): 29-37.

Bromwich, M and Bhimani, A. (1994). Management Accounting: Pathways to Progress. CIMA: London.

Carnoy, M., Castells, M.. Cohen, S.S. and Cardoso, F.H. (1993). The Global Economy in the Information Age: Reflections on our changing world, Pennsylvania State University Press: University Park, Pennsylvania.

Clarke, P. (1993). Management accounting practices in Ireland. Accountancy Ireland, 25(4): 6-8.

Cooper, R. and Kaplan, R.S. (1988). Measure costs right: make the right decisions, Harvard Business Review, 88(5): 96-103.

Cooper, R and Kaplan, R.S. (1991). Profit priorities from activity based costing, Harvard Business Review, 69 (3): 269-280.

Drury, C. (1990). Lost relevance: A note on the contribution of management accounting education, British Accounting Review, 22: 123-135

Drury, C. (1996). Management and Cost Accounting, fourth edition. International Thomson Business Press: London.

Du Plooy, E. (1998). Throughput Accounting - the unpretentious road to profits, Accountancy (SA), October 1998.

Goldratt, E. and Cox, J. (1984). The Goal, Gower: London.

Hansen, D.R. and Mowen, M.M. (1994). Management Accounting, third edition. SouthWestern Publishing Co: Cincinatti, Ohio.

Hendricks, J.A. (1993). The Company \& the Professor - both benefit from faculty internship programs. Management Accounting (USA), April 1993: 47-48. 
Hiromoto, T. (1988). Another hidden edge - Japanese management accounting, Harvard Business Review, 66 (4): 22-26.

Hopper, T. and Armstrong, P. (1991). Cost Accounting, Controlling Labour and the rise of Conglomerates, Accounting, Organizations and Society, 16(5/6): 405-438.

Hopper, T. and Powell, A. (1985). Making sense of research into the organizational and social aspects of management accounting: a review of its underlying assumptions, Journal of Management studies, September 1985: 429-465.

Johnson, H.T. and Kaplan, R.S. (1987). Relevance Lost: The Rise and Fall of Management Accounting, Harvard Business School Press: Boston.

Kaplan, R. S. and Norton, D. P. (1992). Using the balanced scorecard as a strategic management system, Harvard Business Review, 74 (1): 75-85.

Kaplan, R.S. (1994). Management Accounting (1984-1994): development of new practice and theory, Management Accounting Research, 5: 247-260.

Kelly, M. and Pratt, M. (1992). Purposes and paradigms of management accounting: beyond economic reductionism, Accounting Education, 1 (3): 225-246.

Krige, B. (1998). SA's top-rated consultants - 1st ever PMR survey, Professional Management Review, March 1998: 61-63.

Loft, A. (1991). The history of management accounting: relevance found in (ed.) Ashton, D., Hopper, T. \& Scapens, R.W. 1991. Issues in management accounting. Prentice Hall: London.

Lovell, A. (1988). Management Accounting under challenge, Management Accounting (UK), December 1988: 44-47.

Macintosh, N.B. and Scapens, R.W. (1990). Structuration theory in Management Accounting, Accounting, Organizations and Society, 15(5): 455-477.

Maher, M.W. (1995). The evolution of Management Accounting Research, Management Accounting (USA), May 1995: 72.

Miller, P. B. and O'Leary, T. (1987). Accounting and the construction of the governable person. Accounting, Organizations and Society, 12 (3): 235-265.

Neimark, M. and Tinker, T. (1986). The social construction of management control systems. Accounting, Organizations and Society, 11 (4/5): 369-395. 
Rayburn, L.G. (1996). Cost Accounting - using a Cost Managerial Approach, sixth edition. Irwin: Chicago.

Roslender, R. (1996). Relevance lost and found: Critical perspectives on the promise of Management Accounting. Critical Perspectives on Accounting, 7: 533-561.

Scapens, R.W. (1984). Management Accounting - a survey paper. In Scapens, R.W., Otley, D.T and Lister, R.J. (Eds). Management Accounting, Organizational Theory and Capital Budgeting, 15-95, Macmillan: London.

Puxty, A.G. (1993). The Social \& Organizational Context of Management Accounting, International Thomson Business Press, London.

Scapens, R.W. (1991). Management Accounting: A review of recent developments, second edition. Macmillan: Ipswich.

Scapens, R.W. (1994). Never mind the gap: towards an institutional perspective on management accounting, Management Accounting Research, 5:301-21.

Shank, J.K. (1989). Strategic Cost Management: New Wine or Just New Bottles? Journal of Management Accounting Research, Fall 1989: 45-65.

Shank, J.K. and Govindarajan, V. (1989). Strategic Cost Analysis. Irwin: Homewood, Illinois.

Shillinglaw, G. (1980). Old horizons and new frontiers: The future of Management Accounting, in H.P. Holzer (ed), Management Accounting in 1980 - Proceedings of the University of Illinois Management Accounting Symposium, University of Illinois: Chicago.

Siegel, G. and Sorenson, G. (1994). What Corporate America wants in entry-level accountants, Management Accounting (USA), September: 26-31.

Simon, H.A. (1959). Theories of decision-making in economics and behavioural science. The American Economic Review, XLIX (3).

Spencer, C. and Francis, G. (1998). Quantitative skills - do we practice what we preach? Management Accounting (UK), July/August: 64-65.

Turney, P.B.B. and Anderson, B. (1989). Accounting for continuous improvement, Sloan Management Review, 30 (2): 37-47. 
Vorster, Q. (1995). Post Pacioli: Praktyk en Prinsipe, Ongepubliseerde intreerede, Universiteit van Pretoria.

Williamson, D. (1989). Bridging the gap between theory and reality: the need for a partnership. Management Accounting (UK), November 1989. 